\title{
Effect of protein intake on glycaemic control and renal function in Type 2 (non-insulin-dependent) diabetes mellitus
}

\author{
J.Pomerleau ${ }^{1}$, M. Verdy ${ }^{2}$, D. R. Garrel ${ }^{1,2}$, M.Houde Nadeau ${ }^{1}$ \\ ${ }^{1}$ Department of Nutrition, University of Montreal, Montreal, Canada \\ ${ }^{2}$ Division of Endocrinology, Hôtel-Dieu of Montreal, Montreal, Canada
}

\begin{abstract}
Summary. Recent clinical investigations have suggested that dietary protein intake may modulate the progression of diabetic nephropathy and influence glycaemic control in Type 2 (non-insulin-dependent) diabetes mellitus. Twelve normotensive Type 2 diabetic patients with microalbuminuria took part in a randomized cross-over trial of a 3-week high protein diet $(2.0 \mathrm{~g} / \mathrm{kg}$.desirable weight per day) and a $3-$ week moderate protein diet $(0.8 \mathrm{~g} / \mathrm{kg}$ desirable weight per day) to test the simultaneous effect of protein intake modulation on glycaemic control and renal function. Both diets were isoenergetic and the moderate protein diet was supplemented with calcium and phosphate. Renal function and
\end{abstract}

glycaemic control were evaluated at the beginning and at the end of each diet. The moderate protein diet reduced the urinary albumin excretion rate, glomerular filtration rate, creatinine clearance, and proteinuria without adversely affecting glycaemic control; fasting glycaemia and the ratio of fructosamine to proteins were significantly reduced. The high protein diet induced similar improvements in glycaemic control but small changes in renal function.

Key words: Dietary proteins, diabetic nephropathy, glycaemic control, Type 2 (non-insulin-dependent), diabetes mellitus, diet.
It is well known that acute dietary protein ingestion and intravenous injection of amino acids can stimulate pancreatic insulin secretion and reduce postprandial glycaemic response to carbohydrate intake both in Type 2 (non-insulin-dependent) diabetic patients and healthy subjects [1-3]. However, it has been hypothesized that a high protein intake could favour glomerular sclerosis and diabetic nephropathy [4]. Recent studies have explored the effect of protein restriction at different stages of the disease in order to prevent the progression of this problem and have reported reductions of hyperfiltration, proteinuria or albuminuria [5-10]. However, the majority of these studies were carried out in Type 1 (insulin-dependent) diabetic patients, as are most studies on diabetic nephropathy, despite the fact that diabetic nephropathy affects 20 to $40 \%$ of Type 2 diabetic patients [11].

Considering the potential beneficial effect of dietary proteins on glycaemic control in Type 2 diabetes, at least on an acute basis, it is possible that a reduction of protein intake designed to prevent the progression of diabetic nephropathy could impair the metabolic control of these patients. The objective of the present study, therefore, was to explore the effect of two 3-week diets, one high and one moderate in dietary proteins, on both glycaemic control and renal function in a group of obese Type 2 diabetic pa- tients presenting an early stage of diabetic nephropathy; a cross-over design including a 3-week minimal washout period was used.

\section{Subjects and methods}

\section{Description of patients}

The study was performed on 12 obese (body mass index $(\mathrm{BMI})>27 \mathrm{~kg} / \mathrm{m}^{2}$ [12]) Type 2 diabetic patients [13] (eight men and four women) free of hypertension [14] (at the beginning of the study: mean systolic blood pressure: $131 \pm 16.7 \mathrm{~mm} \mathrm{Hg}$; mean diastolic blood pressure: $82 \pm 10.4 \mathrm{~mm} \mathrm{Hg}$ ) and clinical nephropathy [15, 16]. Their mean age was $58 \pm 11$ years, their mean duration of diabetes $10 \pm 8$ years, and their mean BMI $33 \pm 6 \mathrm{~kg} / \mathrm{m}^{2}$. All of the subjects presented microalbuminuria, defined as an albumin excretion rate between 15 and $300 \mu \mathrm{g} / \mathrm{min}$ [17]. Nine patients were treated for their diabetes with oral hypoglycaemic agents and three with diet alone. None of the patients was taking insulin or antihypertensive drugs. The patients' medication was not changed during the study. All subjects gave their written informed consent and the study protocol was approved by the human experiment ethics committees of the HôtelDieu of Montreal and the Clinical Research Institute of Montreal. 
Table 1. Reported dietary composition of usual and experimental diets

\begin{tabular}{lccc}
\hline Nutrient & $\begin{array}{l}\text { Usual } \\
\text { diet } \\
(n=10)\end{array}$ & $\begin{array}{l}\text { High protein } \\
\text { diet }\end{array}$ & $\begin{array}{l}\text { Moderate } \\
\text { protein } \\
\text { diet } \\
(n=10)\end{array}$ \\
\hline Energy (MJ/day) & $9.2 \pm 2.9$ & $9.1 \pm 2.3$ & $8.8 \pm 2.2$ \\
Protein (g/day) & $102 \pm 30$ & $125 \pm 20^{\mathrm{a}}$ & $52 \pm 7^{\mathrm{ab}}$ \\
$(\%$ energy) & $19 \pm 4$ & $22 \pm 4^{\mathrm{a}}$ & $10 \pm 2^{\mathrm{ab}}$ \\
$\left(\mathrm{g} \cdot \mathrm{kg}^{-1} \cdot\right.$ day $\left.^{-1}\right)$ & $1.6 \pm 0.3$ & $1.9 \pm 0.1^{\mathrm{a}}$ & $0.8 \pm 0.0^{\mathrm{ab}}$ \\
Carbohydrate $(\mathrm{g} /$ day) & $243 \pm 105$ & $302 \pm 84$ & $299 \pm 82$ \\
(\% energy) & $43 \pm 9$ & $54 \pm 2^{\mathrm{a}}$ & $56 \pm 2^{\mathrm{a}}$ \\
Fat (g/day) & $92 \pm 32$ & $56 \pm 21^{\mathrm{a}}$ & $80 \pm 26^{\mathrm{b}}$ \\
(\% energy) & $38 \pm 8$ & $22 \pm 4^{\mathrm{a}}$ & $33 \pm 5^{\mathrm{b}}$ \\
Alcohol (g/day) & $5 \pm 12$ & $4 \pm 11$ & $4 \pm 11$ \\
(\% energy) & $2 \pm 4$ & $1 \pm 3$ & $1 \pm 4$ \\
Fibre (g/day) & $21 \pm 12$ & $30 \pm 7^{\mathrm{a}}$ & $31 \pm 8^{\mathrm{a}}$ \\
Calcium (mg/day) & $938 \pm 441$ & $883 \pm 221$ & $930 \pm 221$ \\
Phosphorus (mg/day) & $1586 \pm 712$ & $1336 \pm 295$ & $1369 \pm 295$ \\
\hline
\end{tabular}

${ }^{\mathrm{a}}$ Different from usual diet $(p<0.05)$; ${ }^{\mathrm{b}}$ Different from high protein $\operatorname{diet}(p<0.05)$

\section{Dietary treatments}

Patients were randomly allocated to take in turn a high protein diet (HP diet: $2.0 \mathrm{~g} / \mathrm{kg}$ desirable weight [18] per day) or a moderate protein diet (MP diet: $0.8 \mathrm{~g} / \mathrm{kg}$ desirable weight per day; which is the recommendation of the American Diabetes Association [19]) for 3 weeks. Six patients received the HP diet first. To prevent carryover effects and to allow for the restabilization of protein metabolism [20], there was a minimal 3-week washout period of usual diet between the two treatments (median 4.7 weeks). The diets were isoenergetic and based on the usual diet of the subjects. They were elaborated with the Nutritionist III software from $\mathrm{N}$-Squared Computing. In order to allocate similar intakes of carbohydrate [21], sugar [22], fibre [23] and linoleic acid $[24,25]$, the two diets were based on a single diet representing $85 \%$ of the total energy: $55 \%$ from carbohydrate, $20 \%$ from total fat (including 6 to $8 \%$ from linoleic acid), and $10 \%$ from protein $(0.8 \mathrm{~g} / \mathrm{kg}$ desirable weight per day). The HP diet included an additional $1.2 \mathrm{~g} \cdot \mathrm{kg}^{-1} \cdot \mathrm{day}^{-1}(15 \%$ of the total energy intake) of proteins from supplements (Bariatrix International Inc, Montreal, Canada) made from a mixture of casein, gelatine, vegetable proteins, yeast, and soy. Thirty grammes of lipids (15\% of total energy intake; $62 \%$ saturated and $29 \%$ monounsaturated fatty acids) were added to the MP diet. Calcium and phosphate intakes were made similar through supplementation (tablets) of the MP diet. Individualized 7-day menus were prepared and repeated three times during each experimental period. A detailed food-exchange list was provided to allow small changes in the menus. Subjects were advised to maintain their usual added salt utilisation (salting foods at the table and adding of salt in recipes).

\section{Measurements}

Dietary compliance was assessed at the beginning, in the middle and at the end of each experimental period by 3-day food records ( 2 week-days and 1 weekend day). Compliance to protein intake was also estimated by the measurement of plasma urea and 24 -h urinary urea excretion before, after 1 week and at the end of each experimental period. Protein intake was then calculated using the standard nitrogen balance equation [26] and an equation from $\mathrm{Ma}-$ roni et al. [27]; the results obtained with both formulas were averaged. Plasma and 24-h urinary excretion of calcium and phosphate were measured before and at the end of each diet. Uraemia, calc- aemia, calciuria, and phosphataemia were measured using a Hitachi717 appliance from BMC (Laval, Canada) while urinary urea and phosphates were analysed by a Cobas-Bio device from Roche (Etobicoke, Canada) using standard techniques (urea: urease method, coefficient of variation (CV) $3.0 \%$; calcium: cresolphtaline complexone method, CV $2.0 \%$; phosphates: phosphomolybdate method, CV $3.0 \%$ ). Body weight ( $\pm 0.1 \mathrm{~kg}$ ) was measured at the beginning, after 1 week, and after each diet. Rectification of energy allowance was made after 1 week when necessary. Height was measured before the first treatment $( \pm 0.001 \mathrm{~m})$.

Before and after each treatment, in the fasting state, fructosamine was measured (blue of nitrotetrasolium technique [28], Fructosamine kit and Cobas-Bio device, Roche, Montreal, Canada) and fructosamine/serum protein ratio calculated [29]. After a 12-h fast, subjects were given a breakfast test meal consisting of $250 \mathrm{ml}$ of orange juice, $70 \mathrm{~g}$ of white bread, $5 \mathrm{~g}$ of butter and $21 \mathrm{~g}$ of processed cheese (approximate composition [30]: $67 \mathrm{~g}$ carbohydrate, $12 \mathrm{~g}$ protein, $6 \mathrm{~g}$ fat). The subjects remained in the supine position during the test except while eating the meal $(15 \mathrm{~min})$. Blood samples were taken via a catheter inserted into an arm vein, twice before the meal, then $30,60,120$, and $180 \mathrm{~min}$ after the beginning of the meal. Glycaemia (Hitachi-717 analyser; hexokinase method, CV 2.5\%), insulinaemia (radioimmunoassay, Bio-Mega-Diagnostic Kit; BioMega-Diagnostic Inc., Montreal, Canada; CV 4.3-12.3\% ), and glucagonaemia (radioimmunoassay, RSL Kit; ICN Biomedica, Montreal, Canada; CV $2.0 \%$ ) were measured. The first two measurements were averaged. The pre- and post-treatment 24 -h glycosuria was measured (RA1000 analyser; Technicon, Tarrytown, NY, USA; hexokinase method, CV $2.5 \%$ ).

Before and after each diet, the glomerular filtration rate (GFR) was estimated by the Department of Nuclear Medicine of the HôtelDieu of Montreal using ${ }^{99 m}$ Technicium-DTPA (diethylenetriamine pentaacetic acid) plasma clearance. Twenty-four-hour urine excretion of albumin (RA1000 analyser; turbidimetry with antibodies technique, CV $3.9 \%$ ) and beta-2-microglobulin were measured (Immunoenzymatic assay, Immunoenzymatic essai kit, Hoesch $\mathrm{Ca}-$ nada Inc, Montreal, Canada; CV 6.0\%). Proteinuria, creatininaemia and creatininuria were assessed using a Cobas-Bio device from Roche (proteins: Biuret method, CV $2 \%$; creatinine: alkaline picrate in kinetics, CV $2.0-3.5 \%$ ). Creatinine clearance and fractional clearance of albumin were computed using standard formulas $[9,31]$.

Serum albumin and total proteins were measured before and after each treatment using an Hitachi-717 apparatus (albumin: green of bromocresol in kinetics, CV $2.5 \%$; total proteins: Biuret technique, CV $2.0 \%$ ). Systolic and diastolic blood pressure was measured to the nearest $2 \mathrm{~mm} \mathrm{Hg}$, once with the patient sitting after a 5-min rest and immediately after the patient was standing; the two results were averaged.

\section{Statistical analysis}

Statistical analysis was performed with the SPSS-PC + V3.0 software from SPSS Inc. (Chicago, Ill., USA). Analysis of variance for repeated measures, Wilcoxon tests for paired and unpaired data, and Tukey tests for multiple comparisons were used $[32,33]$. Spearman rank correlation coefficients were calculated. Results for albuminuria, fractional clearance of albumin, beta-2-microglobulinuria, and glycosuria underwent logarithmic transformation prior to statistical analysis because of their skewed distributions. Because of logistical problems, some data are missing for a few variables. When one or more measurements of a variable were missing for a subject, that subject was excluded from the analyses for this variable. The assessment of GFR was complete for nine subjects for each experimental period; consequently, we performed a separate analysis for GFR and fractional clearance of albumin for each diet using Wilcoxon paired tests. Carryover effect was evaluated by the analysis of variance for repeated measures. Systolic arterial pressure presented a significant sequence effect $(p=0.004)$ and was excluded from subsequent analyses. Results are expressed as mean \pm SD. Significance was accepted at the $5 \%$ level. 


\section{Results}

\section{Dietary compliance}

The results of the 3-day food records are presented in Table 1 . The three records were adequately completed by 10 of the 12 subjects. For these subjects, the reported protein intake was increased during the HP diet in comparison to the usual diet (mean increase 19\%), and reduced during the MP diet (mean decrease 50\%). The variation of urinary and serum urea as well as the calculated protein intake from biochemical data (Table 2), confirmed this tendency. Fibre intake and the proportion of energy coming from carbohydrate were increased during both diets while the reported calcium and phosphorus intakes were not modified significantly (Table 1 ). Calcaemia, calciuria, and phosphataemia were not changed significantly by treatments but the calciuria fell significantly during the MP diet despite calcium supplementation $(7.3 \pm 4.2$ to $3.9 \pm 3.2 \mathrm{mmol} /$ day; $p=$ 0.003 ). Although the total energy intake was not changed significantly by the diets, there was a slight but significant

Table 2. Effects of diets on urinary and serum urea and estimated protein intake from biochemical data

\begin{tabular}{|c|c|c|c|}
\hline Variable & $\begin{array}{l}\text { Day 0 } \\
(n=12)\end{array}$ & $\begin{array}{l}\text { Day } 7 \\
(n=12)\end{array}$ & $\begin{array}{l}\text { Day } 20 \\
(n=12)\end{array}$ \\
\hline $\begin{array}{l}\text { Urinary urea (g/day) } \\
\text { High protein diet } \\
\text { Moderate protein diet }\end{array}$ & $\begin{array}{l}402 \pm 127 \\
477 \pm 131\end{array}$ & $\begin{array}{l}508 \pm 197 \\
319 \pm 82^{a}\end{array}$ & $\begin{array}{l}613 \pm 158^{a} \\
277 \pm 89^{a}\end{array}$ \\
\hline $\begin{array}{l}\text { Serum urea }(\mathrm{mmol} / \mathrm{l}) \\
\text { High protein diet } \\
\text { Moderate protein diet }\end{array}$ & $\begin{array}{l}5.7 \pm 2.0 \\
6.0 \pm 2.0\end{array}$ & $\begin{array}{l}7.5 \pm 3.5^{\mathrm{a}} \\
5.2 \pm 1.7^{\mathrm{a}}\end{array}$ & $\begin{array}{c}7.2 \pm 3.0^{\mathrm{a}} \\
4.5 \pm 1.4^{\mathrm{a}}\end{array}$ \\
\hline $\begin{array}{l}\text { Estimated protein intake } \\
\text { from biochemical data } \\
\left(\mathrm{g} \cdot \mathrm{kg}^{-1} \cdot \text { day }\right. \\
\text { High protein diet } \\
\text { Moderate protein diet }\end{array}$ & $\begin{array}{l}1.4 \pm 0.3 \\
1.6 \pm 0.3\end{array}$ & $\begin{array}{l}1.7 \pm 0.5 \\
1.2 \pm 0.2^{2}\end{array}$ & $\begin{array}{l}2.0 \pm 0.5^{\mathrm{a}} \\
1.1 \pm 0.2^{\mathrm{a}}\end{array}$ \\
\hline
\end{tabular}

${ }^{a}$ Different from Day $0(p<0.05)$ decrease in the average body weight during both periods. The average reduction in weight was $1.0 \pm 0.9 \mathrm{~kg}(1 \%$ reduction; $p=0.004$ ) during the $\mathrm{HP}$ diet and $1.9 \pm 1.5 \mathrm{~kg}$ ( $2 \%$ reduction; $p<0.001)$ during the MP diet. No significant correlation was found between the energy intake and body weight changes during the two experimental periods (HP diet: $r=0.16 ; p=0.38$; MP diet: $r=$ $0.002 ; p=0.50$ ). During both treatments, diastolic blood pressure decreased slightly but not significantly (before HP diet: $84 \pm 10.4 \mathrm{mmHg}$; after HP diet: $81 \pm$ $10.7 \mathrm{~mm} \mathrm{Hg}$; before MP diet: $84 \pm 8.5 \mathrm{~mm} \mathrm{Hg}$; after MP diet: $79 \pm 8.4 \mathrm{~mm} \mathrm{Hg} ; p=0.07$ ). No significant differences were observed in serum albumin and total proteins.

\section{Metabolic control and renal function}

Both diets induced significant falls in fasting and 60-min postprandial blood glucose but no significant change in fasting and postprandial insulinaemia (Table 3). There was a significant correlation between fibre intake and fasting glycaemia $(r=-0.65 ; p=0.02)$ at the end of the MP diet, and a significant correlation between fibre intake and fructosamine/serum protein ratio $(r=-0.50 ; p<0.05)$ at the end of the HP diet. During the MP diet, the average weight loss was positively correlated with both the reduction of fasting glycaemia $(r=0.51 ; p<0.07)$ and the reduction of fructosamine/serum protein ratio $(r=0.52$; $p<0.05)$. Postprandial glucagonaemia was significantly reduced at $t=120 \mathrm{~min}$ after each diet.

The ratio of fructosamine to serum proteins decreased significantly after both treatments (Table 4). Glycosuria was slightly but not significantly reduced after both diets. A significant reduction of GFR ( $29 \%$ reduction) after the MP diet was observed (Table 4). Albuminuria also tended to be lower after the MP diet ( $65 \%$ reduction); this reduction was positively correlated with the reduction of protein intake estimated from urinary urea excretion $(r=0.65 ; p=0.01)$. Fractional clearance of albumin was

Table 3. Effects of diets on fasting and postprandial glycaemia, insulinaemia, and glucagonaemia

\begin{tabular}{|c|c|c|c|c|c|}
\hline \multirow[t]{2}{*}{ Variables } & \multirow{2}{*}{$\begin{array}{l}\text { Time } \\
\text { (min) }\end{array}$} & \multicolumn{2}{|c|}{ High protein diet } & \multicolumn{2}{|c|}{ Moderate protein diet } \\
\hline & & Before & After & Before & After \\
\hline $\begin{array}{l}\text { Glycaemia } \\
(\mathrm{mmol} / \mathrm{I}) \\
(n=12)\end{array}$ & $\begin{array}{r}0 \\
30 \\
60 \\
120 \\
180\end{array}$ & $\begin{array}{l}10.7 \pm 3.2 \\
12.0 \pm 3.5 \\
14.4 \pm 3.1 \\
14.8 \pm 2.5 \\
13.6 \pm 2.3\end{array}$ & $\begin{array}{l}10.2 \pm 3.2^{\mathrm{a}} \\
11.6 \pm 3.2 \\
13.5 \pm 2.7^{\mathrm{b}} \\
14.5 \pm 2.7 \\
13.6 \pm 3.6\end{array}$ & $\begin{array}{l}10.7 \pm 3.3 \\
12.4 \pm 3.6 \\
14.3 \pm 3.8 \\
14.8 \pm 3.0 \\
13.4 \pm 3.1\end{array}$ & $\begin{array}{r}9.3 \pm 3.5 \\
11.5 \pm 3.8 \\
12.8 \pm 3.6 \\
13.2 \pm 3.4 \\
12.5 \pm 4.0\end{array}$ \\
\hline $\begin{array}{l}\text { Glucagonaemia } \\
(\rho \mathrm{g} / \mathrm{ml}) \\
(n=11)\end{array}$ & $\begin{array}{r}0 \\
30 \\
60 \\
120 \\
180\end{array}$ & $\begin{array}{l}103 \pm 28 \\
107 \pm 29 \\
107 \pm 30 \\
117 \pm 27 \\
101 \pm 34\end{array}$ & $\begin{array}{l}85 \pm 20 \\
99 \pm 26 \\
99 \pm 29 \\
87 \pm 29^{a} \\
96 \pm 26\end{array}$ & $\begin{array}{l}118 \pm 56 \\
112 \pm 51 \\
130 \pm 66 \\
128 \pm 46 \\
125 \pm 57\end{array}$ & $\begin{array}{c}101 \pm 33 \\
125 \pm 32 \\
115 \pm 48 \\
106 \pm 41^{\mathrm{a}} \\
95 \pm 36\end{array}$ \\
\hline
\end{tabular}

${ }^{\mathrm{a}}$ Different from before the diet $(p<0.05) \quad{ }^{\mathrm{b}}$ Different from before the diet $(p=0.05)$ 
Table 4. Effects of the diets on parameters of glycaemic control and renal function

\begin{tabular}{|c|c|c|c|c|}
\hline \multirow[t]{2}{*}{ Variables $^{\mathrm{a}}$} & \multicolumn{2}{|c|}{ High protein diet } & \multicolumn{2}{|c|}{ Moderate protein diet } \\
\hline & Before & After & Before & After \\
\hline $\begin{array}{l}\text { Fructosamine/ } \\
\text { serum proteins } \\
\text { ratio (mmol/g) }\end{array}$ & $43 \pm 5$ & $40 \pm 5^{b}$ & $44 \pm 7$ & $42 \pm 8^{b}$ \\
\hline $\begin{array}{l}\text { Glycosuria } \\
\text { (mmol/day) }\end{array}$ & $116 \pm 196$ & $91 \pm 120$ & $232 \pm 415$ & $145 \pm 456$ \\
\hline $\begin{array}{l}\text { Glomerular } \\
\text { filtration } \\
\text { rate }\left(\mathrm{ml} \cdot \mathrm{s}^{-1}\right. \\
\left.1.73 \mathrm{~m}^{-2}\right)\end{array}$ & $1.97 \pm 0.47$ & $1.98 \pm 0.64$ & $2.18 \pm 0.77$ & $1.54 \pm 0.80^{c}$ \\
\hline $\begin{array}{l}\text { Albuminuria } \\
(\mu \mathrm{g} / \mathrm{min})\end{array}$ & $98 \pm 105$ & $100 \pm 115$ & $91 \pm 120$ & $55 \pm 57^{d}$ \\
\hline $\begin{array}{l}\text { Fractional } \\
\text { clearance of } \\
\text { albumin }\left(\cdot 10^{6}\right)\end{array}$ & $14.4 \pm 15.5$ & $17.0 \pm 22.3$ & $17.7 \pm 21.3$ & $11.5 \pm 7.2$ \\
\hline $\begin{array}{l}\text { Beta-2-micro- } \\
\text { globulinuria } \\
(\mu \mathrm{g} / \mathrm{l})\end{array}$ & $43 \pm 25$ & $34 \pm 14$ & $43 \pm 25$ & $43 \pm 19$ \\
\hline $\begin{array}{l}\text { Proteinuria } \\
\text { (g/day) }\end{array}$ & $0.33 \pm 0.18$ & $0.28 \pm 0.17^{\circ}$ & $0.33 \pm 0.22$ & $0.24 \pm 0.12^{c}$ \\
\hline $\begin{array}{l}\text { Creatinine } \\
\text { clearance } \\
\left(\mathrm{ml} \cdot \mathrm{s}^{-1}\right. \\
\left.1.73 \mathrm{~m}^{-2}\right)\end{array}$ & $1.73 \pm 0.51$ & $1.67 \pm 0.56^{c}$ & $1.84 \pm 0.59$ & $1.49 \pm 0.62^{\circ}$ \\
\hline
\end{tabular}

${ }^{a} n=12$ except for glycosuria $(n=11)$, GFR $(n=9)$ and fractional clearance of albumin $(n=9)$.

${ }^{\mathrm{b}}$ Different from before the diet $(p<0.01)$,

${ }^{c}$ Different from before the diet $(p<0.05)$,

${ }^{d}$ Different from before the diet $(p=0.05)$, using Wilcoxon paired test using separate analyses for each diet

slightly decreased after the MP diet but this effect did not reach significance. The decrease in fractional clearance of albumin was positively correlated with the reduction of albuminuria $(r=0.65 ; p=0.03)$. Beta-2-microglobulin excretion was not significantly altered by either treatment. Significant reductions in proteinuria and creatinine clearance were observed after both periods. At the end of the HP diet, proteinuria was positively correlated with creatinine clearance $(r=0.54 ; p=0.04)$. Positive correlations were also observed between creatinine clearance and fructosamine/protein ratio after the HP diet $(r=0.59$; $p=0.02$ ), between GRF and fasting glycaemia after the MP diet $(r=0.78 ; p=0.006)$, and between creatinine clearance and fasting glycaemia after the MP diet $(r=0.56 ; p=0.03)$.

\section{Discussion}

The results of the present study indicate that both diets induced an improvement in glycaemic control. In the case of the HP diet, the benefits may have been mediated by the higher protein content of the diet as suggested by the results of previous studies in the diabetic rat [34] and by a clinical study [3]; nevertheless, the amount of dietary proteins allocated in the HP diet was smaller than the amount used in these studies. The reduction of the usual total fat intake during the HP diet may also have contributed to this favourable effect since past findings have shown that a high lipid intake could impair glycaemic control in diabetes, stimulate hepatic gluconeogenesis, and favour insulin resistance [35]. However, the unexpected improvement in glycaemic control following the MP diet suggests that additional factors were present. The increased percentage of energy from carbohydrate, as well as the higher fibre intake during both treatments are possible modulators $[21,36,37]$. Additionally, weight loss has been reported to be a potential modulator of metabolic control in obese Type 2 diabetic patients $[38,39]$; here, the influence of weight loss may have been particularly important during the MP diet.

While both treatments were associated with similar improvements in glycaemic control, the MP diet was followed by more important changes in renal function than the HP diet; this was observed independently of changes in calcium, phosphate or linoleic acid intake, or in blood pressure, all known modulators of renal function $[24,25$, $40,41]$. Microalbuminuria, a predictive marker for the development of clinical proteinuria and diabetic nephropathy in Type 1 and Type 2 diabetes [42-44], was slightly reduced during the MP diet which was significantly associated with the reduction of protein intake. This decrease is consistent with findings in Type 1 diabetes $[5,7,9]$ and with the results of one study in Type 2 diabetes [6]. The observed change in albuminuria does not seem to be of tubular origin since beta-2-microglobulinuria, a marker of tubular reabsorption of albumin [45], was not affected by the MP diet. The modulation of albuminuria, rather, would originate from a modification of the renal haemodynamics, of the filtrating glomerular membrane, or from a combination of these two factors as suggested previously by different authors $[9,46,47]$. In the present study, the reduction of GFR may have induced a fall in the filtered albumin load independently of changes in the plasma albumin concentration at the glomerulus. The slight decrease in the fractional clearance of albumin during the MP diet, as well as its association with the reduction of albuminuria, suggests that a change in the ultrafiltration properties of the glomerular membrane may have contributed to the present findings. A modification of the charge-selectivity properties of the glomerular filter is another possible explanation for the reduction in the albumin excretion rate [48].

The reduction of proteinuria is another favourable change associated with the MP diet $[49,50]$. This decrease was expected; a similar reduction of proteinuria has been reported following protein intake restriction in Type 1 diabetic patients presenting renal failure or clinical proteinuria [47].

Surprisingly, the HP diet did not induce significant adverse effects on renal function; furthermore, proteinuria and creatinine clearance were significantly decreased. The increase in protein intake might have been too small to produce the drastic negative effect on renal function reported by different authors $[4,25,51]$. The type of protein ingested may have also contributed to this result as suggested by studies in healthy subjects $[52,53]$ and in early clinical diabetic nephropathy [54]. Finally, the changes in 
renal function during both diets, may have been mediated by the improvement in glycaemic control as has been suggested by the results of previous clinical work $[55,56]$; the apparent lack of adverse effect on renal function of the HP diet could consequently reflect the offsetting effects of better glycaemic control.

In the present study, dietary compliance was achieved by the patients. Satisfactory compliance occurred despite the usual low fidelity of patients to a diabetic diet or a low protein diet $[57,58]$. The weight loss observed among the subjects was not expected and cannot be explained by the small variation in energy intake reported by the food diaries. Normal variation of body weight, hydric balance, glycogen and muscular stores by exercise may have influenced the results [59]. Also, the energy needs of the subjects may have been underestimated at the beginning of the study, leading to a discrepancy between the energy needs and the actual allowances; it has been suggested that obese persons tend to under report their food intake [60].

In conclusion, the present study suggests that a diet with moderate protein content constitutes a realistic noninvasive method of modulating, at least on a short-term basis, the progression of diabetic nephropathy in Type 2 diabetes. There remains however, a need to explore the long-term effects of such a diet and to clarify the interactions between protein intake reduction, glycaemic control, and weight loss. Contrary to all expectations, the diet high in protein did not adversely affect the kidney function of the subjects. Further investigation of dietary proteins and their effects on renal function in diabetic nephropathy is warranted.

Acknowledgements. We are grateful to Bariatrix Canada Inc. (Montreal, Canada) for its funding assistance and for providing us with the protein supplements; Sandoz Canada Limited (Montreal, Canada) for providing the phosphate supplements; and Ayerst Laboratories (Montreal, Canada) for providing the calcium supplements. J.Pomerleau was supported by grants from the National Health Research and Development Program of Health and Welfare Canada; the Quebec Diabetic Association; the Fonds pour la Formation de Chercheurs et l'Aide à la Recherche du Québec; and the Home Economics Foundation of the University of Montreal.

\section{References}

1. Floyd JC, Fajans SS, Conn JW, Knopf RF, Rull J (1966) Insulin secretion in response to protein ingestion. J Clin Invest 45: 1479 1486

2. Nuttall FQ, Mooradian AD, Gannon MC, Billington C, Krezowski $P$ (1984) Effect of protein ingestion on the glucose and insulin response to a standardized oral glucose load. Diabetes Care 7 : 465-470

3. Seino Y, Seino S, Ikeda M, Matsukura S, Imura H (1983) Beneficial effects of high protein diet in treatment of mild diabetes. Hum Nutr Appl Nutr 37A: 226-230

4. Brenner BM, Meyer TW, Hostetter TH (1982) Dietary protein intake and the progressive nature of kidney disease: the role of hemodynamically mediated glomerular injury in the pathogenesis of progressive glomerular sclerosis in aging, renal ablation, and intrinsic renal disease. N Engl J Med 307: 652-659

5. Dullaart RPF, Beusekamp BJ, Meijer S, van Doormaal JJ, Sluiter WJ (1993) Long-term effects of protein-restricted diet on albuminuria and renal function in IDDM patients without clinical nephropathy and hypertension. Diabetes Care 16: 483492

6. Sugimoto T, Kikkawa R, Haneda M, Shigeta Y (1991) Effect of dietary protein restriction on proteinuria in non-insulin-dependent diabetic patients with nephropathy. J Nutr Sci Vitaminol 37: S87-S92

7. Ciavarella A, Di Mizio G, Stefoni S, Borgnino LC, Vannini P (1987) Reduced albuminuria after dietary protein restriction in insulin-dependent diabetic patients with clinical nephropathy. Diabetes Care 10: 407-413

8. Walker JD, Bending JJ, Dodds RA et al. (1989) Restriction of dietary protein and progression of renal failure in diabetic nephropathy. Lancet II: $1411-1415$

9. Cohen D, Dodds R, Viberti GC (1987) Effect of protein restriction in insulin dependent diabetics at risk of nephropathy. BMJ 294: 795-798

10. Zeller K, Whittaker E, Sullivan L, Raskin P, Jacobson HR (1991) Effect of restricting dietary protein on the progression of renal failure in patients with insulin-dependent diabetes mellitus. New Engl J Med 324: 78-84

11. Krowleski AS, Warram JH, Christlieb AR (1985) Onset, course, complications and prognosis of diabetes mellitus. In: Marble A, Krall LP, Bradley RF, Christlieb AR, Soeldner JS (eds) Joslin's diabetes mellitus. 12th edn. Lea \& Febiger, Philadelphia, pp 251277

12. Zeman FJ (1983) Disorders of energy balance and body weight. In: Zeman FJ (ed) Clinical nutrition and dietetics. The Collamore Press, Lexition, Toronto, pp 555-593

13. National Diabetes Data Group (1979) Classification and diagnosis of diabetes mellitus and other categories of glucose intolerance. Diabetes 28: 1039-1057

14. World Health Organization (1978) Arterial hypertension: report of a WHO Expert Committee. WHO Tech Rep Ser, no 628, Geneva

15. Abuelo JG (1983) Proteinuria: diagnostic principles and procedures. Ann Int Med 98: 186-191

16. Catellier C, Tchobroutsky G (1984) Diabète et rein. In: Catellier C, Tchobroutsky $G$ (eds) Le diabète sucré. Edisem Inc., StHyacinthe, pp 361-369

17. Mogensen CE, Christensen CK, Vittinghus E (1983) The stages in diabetic renal disease with emphasis on the stage of incipient diabetic nephropathy. Diabetes 32 [Suppl 2]: 64-78

18. Metropolitan Life Insurance Company (1983) 1983 Metropolitan height and weight tables. Stat Bull 64: 2-9

19. American Diabetes Association (1987) Nutritional recommendations and principles for individuals with diabetes mellitus. Diabetes Care 10: 126-132

20. Heymsfield SB, Tachilin N, McManus CB, Gerron G (1984) Nitrogen balance. Clinical Consultations $4: 6-10$

21. Brunzell JD, Lerner RL, Hazzard WR, Porte D Jr, Bierman EL (1971) Improved glucose tolerance with high carbohydrate feeding in mild diabetes. N Engl J Med 284: 521-524

22. Wood FC Jr, Bierman EL (1986) Is diet the cornerstone in management of diabetes? N Engl J Med 315: 1224-1227

23. Vinik AE, Jenkins DJA (1988) Dietary fiber in management of diabetes. Diabetes Care 11:160-173

24. Adam O, Wolfram G (1984) Effect of different linoleic acid intakes on prostaglandin biosynthesis and kidney function in man. Am J Clin Nutr 40: 763-770

25. Klahr S, Buerkert J, Purkerson ML (1983) Role of dietary factors in the progression of chronic renal failure. Kidney Int 24: $579-587$

26. Gélinas MD, Beaulieu D, Cadrin M et al. (1987) Evaluation de l'état nutritionnel. In: Gélinas MD (ed) Manuel de nutrition clinique. CPDQ, Montreal, pp 1.2.1-1.2.15

27. Maroni BJ, Steinman TI, Mitch WE (1985) A method for estimating nitrogen intake of patients with chronic renal failure. Kidney Int 27: 58-65

28. Johnson RN, Metcalf JA, Baker JR (1983) Fructosamine: a new approach to the estimation of serum glycosylprotein. An index of diabetic control. Clin Chim Acta 127: 87-95 
29. Ashby JP, Frier BM (1988) Is fructosamine a clinically useful test? Diabetic Med 5: 118-121

30. Health and Welfare Canada (1988) Nutrient values of some common foods. Supply and Services Canada, Ottawa

31. Brenner BM, Dworkin LD, Ichawa I (1986) Glomerular ultrafiltration. In: Brenner BM, Rector FC Jr (eds) The kidney, vol 1. 3rd edn. WB Saunders Company, Philadelphia, pp 124144

32. Norusis MJ (1988) SPSS/PC + Advanced statistics ${ }^{\mathrm{TM}}$ V2.0 for the IBM PC/XT/AT and PS/2. SPSS Inc., Chicago

33. Daniel WW (1987) Biostatistics: a foundation for analysis in the health sciences. 4th edn. John Wiley \& Sons, New York

34. Schmidt FH, Siegel EG, Trapp VE (1980) Metabolic and hormonal investigations in long-term streptozotocin diabetic rats on different dietary regimens. Diabetologia 18: 161-168

35. Anderson JW (1988) Nutritional management of diabetes mellitus. In: Shils ME, Young VR (eds) Modern nutrition in health and disease. 7 th edn. Lea \& Febiger, Philadelphia, pp 1201-1229

36. Hagander B, Asp NG, Efendić S, Nilsson-Ehle P, Scherstén B (1988) Dietary fiber decreases fasting blood glucose levels and plasma LDL concentration in noninsulin-dependent diabetes mellitus patients. Am J Clin Nutr 47: 852-858

37. Riccardi G, Rivellese AA (1991) Effects of dietary fiber and carbohydrate on glucose and lipoprotein metabolism in diabetic patients. Diabetes Care 14:1115-1125

38. Yoshioka N, Kuzuya T, Matsuda A, Iwamoto Y (1989) Effects of dietary treatment on serum insulin and proinsulin response in newly diagnosed NIDDM. Diabetes 38:262-266

39. Laakso M, Uusitupa M, Takala J, Majander H, Reijonen T, Penttilä I (1988) Effects of hypocaloric diet and insulin therapy on metabolic control and mechanisms of hyperglycemia in obese non-insulin-dependent diabetic subjects. Metabolism 37: 10921100

40. Parving HH (1991) Impact of blood pressure and antihypertensive treatment on incipient and overt nephropathy, retinopathy, and endothelial permeability in diabetes mellitus. Diabetes Care $14: 260-269$

41. Alfrey AC(1988) Effect of dietary phosphate restriction on renal function and deterioration. Am J Clin Nutr 47: 153-156

42. Viberti GC, Jarrett RJ, Mahmud U, Hill RD, Argyropoulos A, Keen H (1986) Microalbuminuria as a predictor of clinical nephropathy in insulin-dependent diabetes mellitus. Lancet I: 1430-1432

43. Messent JWC, Elliott TG, Hill RD, Jarrett RJ, Keen H, Viberti GC (1992) Prognostic significance of microalbuminuria in insulin-dependent diabetes mellitus: a twenty-three year follow-up study. Kidney Int 41: 836-839

44. Mogensen CE (1984) Microalbuminuria predicts proteinuria and early mortality in maturity-onset diabetes. N Engl J Med 310: $356-360$

45. Portman RJ, Kissane JM, Robson AM (1986) Use of $\beta 2$ microglobulin to diagnose tubulo-interstitial renal lesions in children. Kidney Int 30: 91-98

46. Yue DK, O'Dea J, Stewart P, et al. (1988) Proteinuria and renal function in diabetic patients fed a diet moderately restricted in protein. Am J Clin Nutr 48: 230-234
47. Anderson S (1990) Low protein diets and diabetic nephropathy. Semin Nephrol 10: 287-293

48. Giordano C, Capodicasa G, DeSanto NG (1984) Effects of various diets on the progression of human and experimental uraemia. Proceedings of European Dialysis and Transplant Association-European Renal Association. 21: 549-557

49. Borch-Johnsen K, Andersen PK, Deckert T (1985) The effect of proteinuria on relative mortality in type 1 (insulin-dependent) diabetes mellitus. Diabetologia 28: 590-596

50. Nelson RG, Pettitt DJ, Carraher MJ, Baird HR, Knowler WC (1988) Effect of proteinuria on mortality in NIIDM. Diabetes 37: 1499-1504

51. Kupin WL, Cortes P, Dumler F, Feldkamp CS, Kilates MC, Levin NW (1987) Effect on renal function of change from high to moderate protein intake in type 1 diabetic patients. Diabetes 36 : 73-79

52. Jones MG, Lee K, Swaminithan R (1987) The effect of dietary protein on glomerular filtration rate in normal subjects. Clin Nephrol 27: 71-75

53. Kontessis PS, Dodds RA, Jones SJ, Viberti GC(1988) The effect of different sources of dietary protein on renal function in healthy subjects. Kidney Int 33: 411 (Abstract)

54. Jibani MM, Bloodworth LL, Foden E, Griffiths KD, Galpin OP (1991) Predominantly vegetarian diet in patients with incipient and early clinical diabetic nephropathy: effects on albumin excretion rate and nutritional status. Diabetic Med 8:949-953

55. Dahl-Jørgensen K, Bjoro T, Kierulf P, Sandvik L, Bangstad HJ, Hanssen KF (1992) Long-term glycemic control and kidney function in insulin-dependent diabetes mellitus. Kidney Int 41 : 920-923

56. Vasquez B, Flock EV, Savage PJ et al. (1984) Sustained reduction of proteinuria in type 2 (non-insulin-dependent) diabetes following diet-induced reduction of hyperglycaemia. Diabetologia 26: 127-133

57. Cerkoney KAB, Hart LD (1980) The relationship between the health belief model and compliance of persons with diabetes mellitus. Diabetes Care 3: 594-598

58. Savage PJ, Knowler WC (1984) Diet therapy for type II diabetes mellitus: can new approaches improve therapeutic results? Nutr Abstr Res: Rev Clin Nutr 54: 69 (Abstract)

59. Khosla T, Billewicz WZ (1964) Measurement of change in bodyweight. Br J Nutr 18:227-239

60. Witschi JC (1990) Short-term dietary recall and recording methods. In: Willet W (ed) Nutritional epidemiology. Oxford University Press, New York, Oxford, pp 52-68

Received: 13 November 1992

and in revised form: 16 April 1993

J. Pomerleau

Department of Epidemiology and Biostatistics

University of Western Ontario

Kresge Building

Ontario

Canada, N6A 5C1 